\title{
2021 Handbook of Florida Water Regulation: Resource Conservation and Recovery Act ${ }^{1}$
}

\author{
Michael T. Olexa, Tatiana Borisova, and Jana Caracciolo
}

\section{Preface}

This handbook is designed to provide an accurate, current, and authoritative summary of the principal federal and state (Florida) laws that directly or indirectly relate to agriculture. This handbook provides a basic overview of the many rights and responsibilities that farmers and farmland owners have under both federal and state laws as well as the appropriate contact information to obtain more detailed information. However, the reader should be aware that because the laws, administrative rulings, and court decisions on which this handbook is based are subject to constant revision, portions of this publication could become outdated at any time. Several details of cited laws are also left out due to space limitations. This handbook is provided as an educational text for those interested in water use and water resource issues in Florida.

This handbook is distributed with the understanding that the authors are not engaged in rendering legal or other professional advice, and the information contained herein should not be regarded as a substitute for professional advice. This handbook is not all inclusive in providing information to achieve compliance with the federal and state laws and regulations governing water protection. For these reasons, the use of these materials by any person constitutes an agreement to hold harmless the authors, the UF/IFAS Center for Agricultural and Natural Resource Law, and UF/IFAS Extension for any liability claims, damages, or expenses that may be incurred by any person as a result of reference to or reliance on the information contained in this handbook. Note: UF/IFAS is the acronym for University of Florida, Institute of Food and Agricultural Sciences.

\section{RCRA Overview}

The Resource Conservation and Recovery Act (RCRA) is a comprehensive authority for all aspects of managing hazardous wastes (i.e., wastes that are potentially harmful to human health or the environment) as well as non-hazardous solid wastes. RCRA contains separate requirements for waste generators and transporters, and for the facilities for treatment, storage, or disposal of hazardous waste. These requirements, which include permitting for many facilities and exhaustive recordkeeping for all phases of management, are intended to track the movement and handling of the hazardous waste until it reaches its final point of disposal. This is known as the cradle-to-grave approach to monitoring hazardous wastes.

RCRA sets out standards for the disposal of solid wastes and it classifies wastes according to these categories:

- Trash, garbage, and sludge

- Liquid, semi-solid waste, and contained gases

1. This document is FE583, one of a series of the Food and Resource Economics Department, UF/IFAS Extension. Original publication date October 1998. Revised June 2017 and April 2021. Visit the EDIS website at https://edis.ifas.ufl.edu for the currently supported version of this publication.

2. Michael T. Olexa, professor, Food and Resource Economics Department, and director, UF/IFAS Center for Agricultural and Natural Resource Law, UF/ IFAS Extension, and member of The Florida Bar; Tatiana Borisova, associate professor, Food and Resource Economics Department; and Jana Caracciolo, student, Levin College of Law; UF/IFAS Extension, Gainesville, FL 32611.

The Institute of Food and Agricultural Sciences (IFAS) is an Equal Opportunity Institution authorized to provide research, educational information and other services

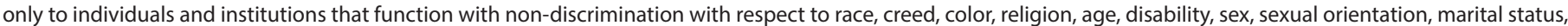

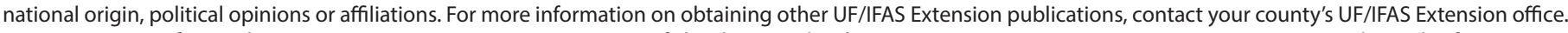
U.S. Department of Agriculture, UF/IFAS Extension Service, University of Florida, IFAS, Florida A \& M University Cooperative Extension Program, and Boards of County Commissioners Cooperating. Nick T. Place, dean for UF/IFAS Extension. 
- Wastes resulting from industrial, commercial, mining, and agricultural operations

\section{What is exempt from RCRA disposal standards?}

Domestic sewage, irrigation return flow, or pollutants from point sources covered under the National Pollution Discharge Elimination System (NPDES) permits of the Clean Water Act (see FE582) are not considered solid wastes and are therefore not subject to RCRA's disposal standards. Source material, special nuclear material, or byproduct material as defined by the Atomic Energy Act of 1954 are also not considered solid wastes and are therefore not subject to RCRA's disposal standard.

\section{Who enforces RCRA?}

The United States Environmental Protection Agency (EPA) is responsible for implementing and enforcing RCRA, for establishing the criteria for classifying "hazardous" wastes, and for listing those wastes to which RCRA automatically applies. RCRA also permits states to enact and enforce their own hazardous waste programs. For a state to act in lieu of EPA, a state must pass an act that is at least as strict as the EPA regulations and must be approved by EPA. Florida is authorized to administer all aspects of RCRA's "base program" (i.e., most facets of RCRA that were passed before 1986).

\section{How is RCRA enforced?}

Permits are required under RCRA for anyone who owns or operates a facility for the treatment, storage, or disposal of hazardous wastes. Generators and transporters may operate without an EPA permit, but must obtain an EPA identification number (EPAID) and may be required to file reports with EPA via the national e-manifest system at regular intervals depending on the quantity and type of wastes they handle.

EPA retains broad authority to require tests, inspections, or additional monitoring when it determines that there is an enhanced danger to health or the environment from the facility. This is especially true with regard to permitted hazardous waste facilities. If EPA determines that a person has violated any provision of RCRA, EPA may issue compliance orders requiring immediate or timely compliance and may suspend or revoke the permit for noncompliance. In contrast to hazardous waste facilities, no federal permits are required for non-hazardous solid-waste disposal although there are federal regulations on the subject.
EPA has a cleanup enforcement program that makes those responsible for leaking hazardous substances from underground tanks to either clean it up or reimburse the EPA for its cleanup. Underground tanks that leak hazardous materials pose a potential threat to contaminating drinking water. Therefore, RCRA $\$ 9003(\mathrm{~h})$ provides EPA with the authority to enforce the cleanup of leaking underground storage tanks when one of the following occurs:

\section{1.the release poses a major public health or environmental emergency}

2.the state or the owner/operator is unable to respond

3. the state requests assistance from EPA

The EPA may issue a corrective action order to compel underground storage tank owners to take cleanup action.

\section{What are the penalties under RCRA?}

EPA may issue its own administrative rulings to collect the expenses it incurs by monitoring or testing. EPA is also empowered to initiate civil actions to enforce its orders or rules.

RCRA authorizes private citizens to bring civil lawsuits to enforce its provisions against offenders in addition to allowing citizen lawsuits against the EPA or state administrator to compel enforcement of RCRA.

RCRA provides for civil penalties for up to $\$ 25,000$ per day for noncompliance for each violation of a requirement of RCRA. The extent of criminal penalties will depend on whether violators knew they were violating RCRA at the time of the offense:

1. A fine of $\$ 50,000$ per day and up to five years' imprisonment if the violator knowingly transported or caused to be transported any hazardous waste to a facility that did not have a permit, or if the violator knowingly treated, stored, or disposed of any hazardous waste without a permit or had knowledge of a violation of any material condition or requirement of the permit, applicable temporary standing regulations, or standards.

2. A fine of $\$ 250,000$ per day and 15 years' imprisonment if the violator knowingly placed others in danger. The organization that is in noncompliance can be subject to up to a one-million-dollar fine on conviction of individuals associated with it. 
Noncompliance with an EPA corrective action order to clean-up a underground storage tank leak can result in fines up to $\$ 37,500$ per day.

\section{Sources}

42 United States Code, Sections 6901 to 6987

For further information about RCRA, consult the EPA website for Hazardous Wastes Quick Finder (http://www.epa. gov/osw/hazard/index.htm) and Summary of the Resource Conservation and Recovery Act (https://www.epa.gov/rcra/ resource-conservation-and-recovery-act-rcra-overview).

\section{Acknowledgments}

The authors are indebted to the personnel of both state and federal agencies who provided their time and advice in the preparation of this handbook. We acknowledge Carol Fountain and Susan Gildersleeve at the University of Florida for their assistance in editing this handbook. We also acknowledge funding received for updating this publication from the James S. and Dorothy F. Wershow UF/ IFAS Center for Agricultural and Natural Resource Law Endowment. 